\title{
Ethylene Does Not Promote Adventitious Root Initiation on Apple Microcuttings
}

\author{
James F. Harbage ${ }^{1}$ and Dennis P. Stimart ${ }^{2}$ \\ Department of Horticulture, University of Wisconsin, 1575 Linden Drive, Madison, WI 53706
}

Additional index words. tissue culture, micropropagation, rooting, adventitious roots

\begin{abstract}
We investigated the role of ethylene on adventitious rooting of 'Gala' (easy-to-root) and 'Triple Red Delicious' (difficult-to-root) apple (Malus domestica Borkh.) microcuttings. Root count increased significantly as IBA level increased, with highest root counts on 'Gala'. Ethylene evolution increased significantly with IBA level without significant differences between cultivars. Basal section removal of microcuttings in the area of root origin reduced root count without changing ethylene evolution. Ethylene treatment of proliferated shoots before microcutting excision failed to enhance rooting. IBAinduced ethylene evolution was eliminated nearly by AVG, but root count remained IBA dependent. ACC reversed IBA plus AVG rooting inhibition, but ACC alone failed to influence root count. Polar auxin transport inhibitors NPA and TIBA stimulated ethylene evolution without increasing root count. Adventitious rooting of apple microcuttings was not associated with ethylene. Chemical names used: 1 - $H$-indole-3-butyric acid(IBA); aminoethoxyvinylglycine(AVG); 1-aminocyclopropane1-carboxylic acid (ACC); 2,3,5-triiodobenzoic acid (TIBA); $N$-1-naphthylphthalamic acid (NPA).
\end{abstract}

Acetylene, carbon monoxide, ethylene, and propylene stimulate adventitious rooting (Zimmerman et al., 1933; Zimmerman and Hitchcock, 1933), with ethylene the most effective. Further research was eclipsed by discovery of indole-3-acetic acid as a rooting aid (Thimann and Koepfli, 1935; Thimann and Went, 1934). Discovery that auxin stimulated formation of ACC and ethylene (Yu and Yang, 1979) renewed interest in auxin and ethylene involvement in adventitious rooting. However, research results remain inconsistent. Ethylene can be stimulatory (Jusaitis, 1986; Riov and Yang, 1989; Robbins et al., 1983, 1985), inhibitory (Geneve and Heuser, 1983; Geneve et al. 1990a), or without relationship (Batten and Mullins, 1978; Mudge and Swanson, 1978) to adventitious rooting. Explanation, in part, may reside in experimental protocols and genetically variable plant material. Most studies used herbaceous materials with variations of the Vigna radiata (L.) R. Wilcz. bioassay (Hess, 1968). Few studies used woody species (Moncousin et al., 1989; Swanson, 1974) or difficult-to-root plants (Geneve et al., 1990a, 1990b).

Apple (Malus domestica) microcuttings are useful to study adventitious root formation (Zimmerman and Fordham, 1985). They are clonal, root readily with specific root initiation treatments, and vary by cultivar in capacity to root. We examined the involvement of ethylene in adventitious root initiation of $M$. domestica microcuttings.

\section{Materials and Methods}

Shoot culture.Malus domestica 'Gala' (easy-to-root) and 'Triple Red Delicious' (difficult-to-root) cultured shoots were obtained from Richard H. Zimmerman, U.S. Dept. Agriculture, Beltsville, Md. Shoot cultures were proliferated by transferring shoots or shoot clumps to fresh medium containing Murashige-Skoog (MS) minerals (Murashige and Skoog, 1962), 0.56 mm myo-inositol, 1.2 $\mu_{\mathrm{M}}$ thiamine $\mathrm{HCl}, 1.3 \mu \mathrm{M}$ gibberellic acid, $0.49 \mu \mathrm{M}$ IBA, $4.44 \mu \mathrm{M}$

Received for publication 22 Sept. 1995. Accepted for publication 7 Mar. 1996. Use of trade names does not imply endorsement of the products named nor criticism of similar ones not named. The cost of publishing this paper was defrayed in part by the payment of page charges. Under postal regulations, this paper therefore must be hereby marked advertisement solely to indicate this fact.

${ }^{1}$ Graduate research assistant.

${ }^{2}$ Professor; to whom reprint requests should be addressed. benzylaminopurine, $88 \mathrm{~mm}$ sucrose, and $0.7 \mathrm{~g} \cdot \mathrm{L}^{-1}$ Difco Bacto agar at 4-week intervals. Cultures were incubated under continuous 40 $\mu \mathrm{mol} \cdot \mathrm{m}^{-2} \cdot \mathrm{s}^{-1}$ cool-white fluorescent light at $21{ }^{\circ} \mathrm{C}$, unless otherwise specified.

Root initiation and root development. Root initiation and root development incubations took place in $25 \times 90$-mm glass shell vials. One microcutting was placed in a plastic support in the shell vial with the basal $4 \mathrm{~mm}$ of the microcutting in $3 \mathrm{~mL}$ of medium. Root initiation treatment consisted of treating the basal end of five-node, 30- to 35day-old apical shoot microcuttings with liquid root initiation medium containing $1.5 \mu \mathrm{M} \mathrm{IBA}$ and $44 \mathrm{~mm}$ sucrose (pH 5.6). Dark incubation at $30^{\circ} \mathrm{C}$ for $4 \mathrm{~d}$ (unless specified) was used to promote adventitious root primordia formation (Harbage et al., 1993).

After root initiation, root development treatment consisted of treating microcutting basal ends with liquid half-strength MS minerals (minus Fe) and $22 \mathrm{~mm}$ sucrose. Development occurred under continuous $30 \mu \mathrm{mol} \cdot \mathrm{m}^{-2} \cdot \mathrm{s}^{-1}$ cool-white fluorescent light at $23^{\circ} \mathrm{C}$ (Harbage et al., 1993). Roots were counted after $14 \mathrm{~d}$.

Shoot culture, root initiation, and root development media were autoclaved at $1.3 \mathrm{~kg} \cdot \mathrm{cm}^{-2}$ at $121^{\circ} \mathrm{C}$ for $15 \mathrm{~min}$.

Gas evolution. Ethylene was measured on a gas chromatograph (GC9A; Shimadzu) equipped with a 1 or $2 \mathrm{~m} \times 2 \mathrm{~mm}$ (i.d.) Poropak $Q$ packed stainless-steel column and a flame ionization detector. Carrier gas was nitrogen at 60 to $80 \mathrm{~mL} \cdot \mathrm{min}^{-1}$. Temperatures were isothermal: $150{ }^{\circ} \mathrm{C}$ for injector and detector and $40{ }^{\circ} \mathrm{C}$ for the column oven. Gas accumulated in the microcutting vials. Vials were sealed with rubber stoppers fitted with glass tubes and rubber serum caps for $24 \mathrm{~h}$ on day 4 of the $4-\mathrm{d}$ root initiation treatment (unless specified). Two-milliliter gas samples were drawn with a syringe and injected into the gas chromatograph. Ethylene measurement was converted from $\mathrm{ppm}$ readings to $\mathrm{nl} \cdot \mathrm{g}^{-1} \cdot \mathrm{h}^{-1}$ based on shell vial volume $(0.032 \mathrm{~L})$, microcutting fresh weight (about 0.05 $\mathrm{g})$, and incubation duration $(24 \mathrm{~h})$. Treatments were given to $M$. domestica 'Gala', from start through end of root initiation, unless specified. Ethylene was measured on day 4 of root initiation, unless specified. Root count data were taken day 14 of root development. Completely random designs were used unless specified.

Ethylene evolution during root initiation. Ethylene release from 'Gala' and 'Triple Red Delicious' was examined during root initiation in media containing $0,0.15,1.5,15$, or $150 \mu \mathrm{M}$ IBA. There were 5 replications for ethylene measurements and 10 to 14 replications for root counts. 
Table 1. Ethylene evolution and root count from Malus domestica 'Gala' and 'Triple Red Delicious' microcuttings treated with IBA in root initiation medium.

\begin{tabular}{|c|c|c|c|}
\hline Main effect & $\mathrm{df}$ & Ethylene $\left(\mathrm{nl} \cdot \mathrm{g}^{-1} \cdot \mathrm{h}^{-1}\right)$ & Root count \\
\hline \multicolumn{4}{|l|}{ Cultivar } \\
\hline Gala & & 9.31 & 7.9 \\
\hline Triple Red Delicious & & 10.88 & 4.3 \\
\hline \multicolumn{4}{|l|}{$\operatorname{IBA}(\mu \mathrm{M})$} \\
\hline 0 & & 2.64 & $1.7^{\mathrm{z}}$ \\
\hline 0.15 & & 3.62 & 5.6 \\
\hline 1.5 & & 4.46 & 9.2 \\
\hline 15 & & 8.44 & 10.2 \\
\hline 150 & & 31.32 & 4 \\
\hline ANOVA $^{z}$ & & \multicolumn{2}{|c|}{ Mean square } \\
\hline Cultivar (C) & 1 & $0.59^{\mathrm{NS}}$ & $15.35^{* * *}$ \\
\hline IBA & 4 & $23.82^{* * * *}$ & $11.07^{* * *}$ \\
\hline $\mathrm{C} \times \mathrm{IBA}$ & 4 & $0.32^{\mathrm{NS}}$ & $0.79^{\mathrm{NS}}$ \\
\hline Error & $40,110^{y}$ & 0.33 & 1.21 \\
\hline
\end{tabular}

Ethylene origin. Basal sections of microcuttings were removed before ethylene measurement to determine ethylene origin. Sections $0,1,2,4,6,8$, or $10 \mathrm{~mm}$ long from 25 -mm-long microcuttings were removed and discarded after day 2 of root initiation in response to $15 \mu \mathrm{M}$ IBA. Shortened microcuttings were placed in medium lacking IBA. Vial capping was delayed for $6 \mathrm{~h}$ after excision to vent wound ethylene. Ethylene was measured on day 3 using 12 to 14 replications per treatment.

Ethylene inhibitor and promoter studies. Influence of 0, 0.06, $0.13,0.25,0.5,1$, or $2 \mu \mathrm{M} A V G$ on ethylene evolution and rooting was tested. Ethylene was measured on days 2 and 4 of root initiation using 10 replications per treatment.

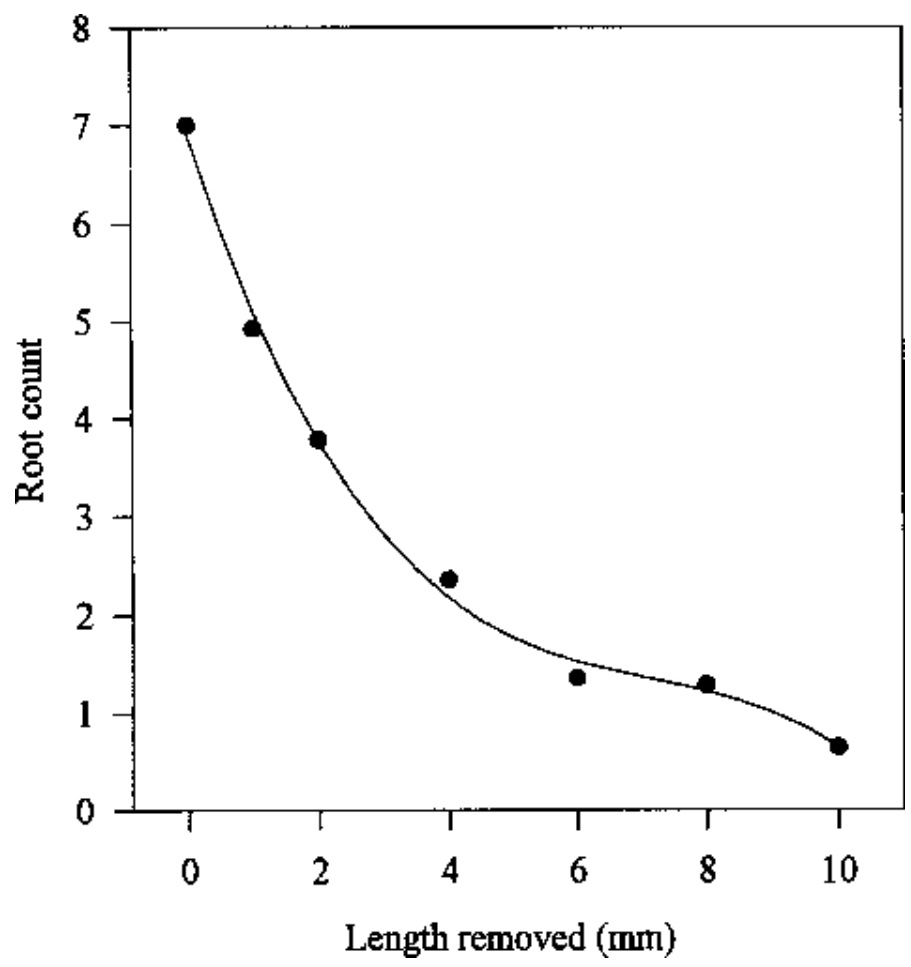

Fig. 1. Root count of Malus domestica 'Gala' microcuttings after removal of basal stem portions.
Interaction between AVG and IBA on ethylene evolution and rooting was evaluated. Factorial combinations of 1.5 or $15 \mu \mathrm{M}$ IBA and 0,10 , or $100 \mu \mathrm{M}$ AVG were used. A randomized completeblock design was used with 2 blocks and 10 samples per treatment.

ACC, AVG, and IBA were tested in combinations to determine ethylene evolution and rooting patterns. Treatments include those given in Table 3. There were 9 or 10 replications per treatment.

Ethylene treatment. Ethylene at $0,0.1,1,10,100$, or 1000 $\mu \mathrm{L} \cdot \mathrm{L}^{-1}( \pm 5 \%)$ was prepared from $99.5 \%$ ethylene and compressed air. Gas was delivered in a flow-through system for $6 \mathrm{~d}$ before excision of proliferated shoots to determine rooting response. A randomized complete-block design was used with 2 blocks and 10 samples per treatment.

Auxin transport inhibitors. Ethylene evolution and rooting were examined in response to NPA and TIBA. Inhibitors were added to root initiation medium before autoclaving. NPA and IBA were used at $0,1.5$, or $15 \mu \mathrm{m}$ in factorial combination. TIBA and IBA were used at $0,0.15,1.5$, or $15 \mu_{\mathrm{M}}$ in factorial combination. There were 8 to 10 replications per treatment.

Data for all experiments were analyzed using the General Linear Models Procedure (SAS Institute, Cary, N.C.). Transformation of some data sets was used to normalize variance versus mean distributions.

\section{Results}

Ethylene evolution during root initiation. 'Gala' and 'Triple Red Delicious' differed significantly for root count but not for ethylene evolution when treated with IBA (Table 1). IBA concentration significantly affected root count and ethylene evolution. Increasing IBA increased ethylene evolution. Root count increased with IBA up to $15 \mu \mathrm{M}$ then decreased. There was no significant interaction between cultivar and IBA on ethylene evolution or root count.

Ethylene origin. Basal section removal had no significant influence on ethylene evolution (data not shown) but significantly reduced root count $\left(\mathrm{y}=6.9098-2.0606(\mathrm{x})+0.2697\left(\mathrm{x}^{2}\right), r^{2}=0.9967\right.$; Fig. 1). Ethylene evolution ranged from 3.10 to $4.29 \mathrm{nl} \cdot \mathrm{g}^{-1} \cdot \mathrm{h}^{-1}$. As the amount of basal section removed increased, root count decreased. The most rapid decrease was between 0 to $4 \mathrm{~mm}$. Removal from 4 to $10 \mathrm{~mm}$ resulted in only slightly lower root counts. 


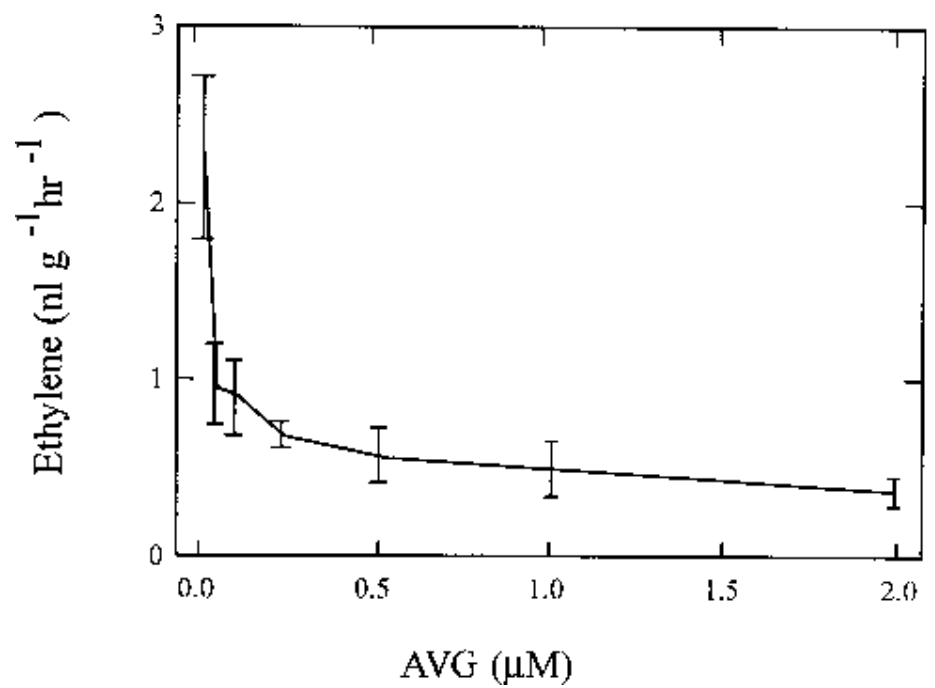

Fig. 2. Ethylene evolution from Malus domestica 'Gala' microcuttings in response to AVG in root initiation medium after $4 \mathrm{~d}$ of treatment. Vertical bars represent \pm sE. Analysis of variance for AVG level was significant $(P=0.001)$.

Ethylene inhibitor and promoter studies. Ethylene evolution was decreased significantly by AVG addition (Fig. 2). The decline was sharp between 0 and the lowest concentration tested $(0.25 \mu \mathrm{M}$ AVG). Higher concentrations only showed a slight decrease from 0.25 to $2 \mu \mathrm{M}$ AVG.

The IBA $\times$ AVG interaction was significant for ethylene evolution and not root count (Table 2). AVG added to the media reduced ethylene evolution. IBA and AVG significantly affected root count. Root count increased as IBA added increased but decreased as AVG added increased.

Adding ACC increased ethylene evolution but did not increase root count (Table 3). Adding IBA did not cause an increase in ethylene but increased root count. Adding IBA and AVG eliminated nearly ethylene evolution and decreased root count compared to IBA alone. Adding ACC with IBA and AVG overcame the affect of AVG on root count and increased the evolution of ethylene.

Ethylene treatment. Treating with ethylene before root initiation treatment had no significant affect on root count, which ranged from 7.3 to 9.0 (data not shown). Root initiation IBA treatment nearly doubled root count (from 9.0 to 16.6 roots), regardless of ethylene level. There was no significant IBA $\times$ ethylene interaction.

Auxin transport inhibitors. Ethylene evolution was increased significantly by adding IBA, NPA (Table 4), or TIBA (Table 5). There was no significant IBA $\times$ NPA or IBA $\times$ TIBA interaction for ethylene evolution. Root count was not affected significantly by NPA but by an IBA $\times$ TIBA interaction (Table 5). As IBA increased, root count increased, but adding TIBA decreased root count (Fig. 3).

\section{Discussion}

This research strongly suggests that ethylene is not involved in auxin-dependent (IBA) root formation in apple microcuttings. Experiments showed that ethylene evolution and root count were linked to increasing auxin concentration (Table 1). Ethylene evolution was independent of genetic differences in rooting ability. Easy-to-root 'Gala' produced more roots than difficult-to-root 'Triple Red Delicious', but no significant differences in ethylene evolution existed between cultivars (Table 1). Ethylene evolution was not associated with the root formation zone as observed when the basal sections were removed. Ethylene was released at similar rates even as the root forming zone was reduced and root count was eliminated (Fig. 1). Treatment with ethylene gas did not eliminate the IBA requirement for root formation. Geneve et al. (1990a) found auxin stimulated ethylene in adult (very-difficult-to-root) and juvenile (easy-to-root) Hedera helix $\mathrm{L}$. petiole cuttings, but the evolution from adult petioles was similar or greater than juvenile.

Table 2. Ethylene evolution and root count Malus domestica 'Gala' microcuttings in response to AVG and IBA in root initiation medium.

\begin{tabular}{|c|c|c|c|c|}
\hline \multicolumn{2}{|c|}{ Treatment } & \multirow[b]{2}{*}{ df } & \multirow[b]{2}{*}{ Ethylene $\left(\mathrm{nl} \cdot \mathrm{g}^{-1} \cdot \mathrm{h}^{-1}\right)$} & \multirow[b]{2}{*}{ Root count } \\
\hline IBA $(\mu \mathrm{M})$ & $\operatorname{AVG}(\mu \mathrm{M})$ & & & \\
\hline 1.5 & 0 & & 3.67 & \\
\hline 1.5 & 10 & & 0.00 & \\
\hline 1.5 & 100 & & 0.07 & \\
\hline 15 & 0 & & 7.11 & \\
\hline 15 & 10 & & 0.34 & \\
\hline 15 & 100 & & 0.07 & \\
\hline \multicolumn{5}{|c|}{$\mathrm{AVG}(\mu \mathrm{M})$} \\
\hline 0 & & & & 15.5 \\
\hline 10 & & & & 10.3 \\
\hline 100 & & & & 1.3 \\
\hline \multicolumn{5}{|l|}{$\mathrm{IBA}(\mu \mathrm{M})$} \\
\hline 1.5 & & & & 5.7 \\
\hline 15 & & & & 12.3 \\
\hline ANOVA $^{\mathrm{z}}$ & & & & \\
\hline Block & & 1 & $0.006^{\mathrm{NS}}$ & $0.081^{\mathrm{NS}}$ \\
\hline IBA & & 1 & $0.045^{* *}$ & $6.722^{* * * *}$ \\
\hline $\mathrm{AVG}$ & & 2 & $5.510^{* * * *}$ & $13.950^{* * * *}$ \\
\hline $\mathrm{IBA} \times$ & & 2 & $0.247^{* * *}$ & $0.156^{\mathrm{NS}}$ \\
\hline Error & & 16 & 0.038 & 0.1 \\
\hline
\end{tabular}

${ }^{\mathrm{z}}$ Analysis of variance of transformed data $(\sqrt{\mathrm{x}}+1)$ for ethylene and root count. Nontransformed means presented. Ns, ${ }^{* *}, * * * N$ Nonsignificant or significant at $P=0.01$ or 0.001 , respectively. 
Table 3. Influence of IBA, AVG, and ACC on ethylene evolution and root count of Malus domestica 'Gala' microcuttings.

\begin{tabular}{|c|c|c|c|c|c|}
\hline \multicolumn{3}{|c|}{ Treatment } & \multirow[b]{2}{*}{ df } & \multirow[b]{2}{*}{ Ethylene $\left(\mathrm{nl} \cdot \mathrm{g}^{-1} \cdot \mathrm{h}^{-1}\right)$} & \multirow[b]{2}{*}{ Root count } \\
\hline IBA $(\mu \mathrm{M})$ & $\mathrm{AVG}(\mu \mathrm{M})$ & $\mathrm{ACC}(\mu \mathrm{M})$ & & & \\
\hline$\overline{0}$ & 0 & 0 & & $2.87 \mathrm{c}^{\mathrm{z}}$ & $2.5 \mathrm{c}$ \\
\hline 0 & 0 & 2 & & $5.59 \mathrm{~b}$ & $2.1 \mathrm{c}$ \\
\hline 1.5 & 0 & 0 & & $3.16 \mathrm{c}$ & $11.1 \mathrm{a}$ \\
\hline 1.5 & 0 & 2 & & $5.50 \mathrm{~b}$ & $10.0 \mathrm{a}$ \\
\hline 1.5 & 2 & 0 & & $0.51 \mathrm{~d}$ & $5.3 \mathrm{~b}$ \\
\hline 1.5 & 2 & 2 & & $5.38 \mathrm{~b}$ & $8.1 \mathrm{ab}$ \\
\hline 1.5 & 2 & 20 & & $19.26 \mathrm{a}$ & $12.2 \mathrm{a}$ \\
\hline \multicolumn{4}{|l|}{ ANOVA } & \multicolumn{2}{|c|}{ Mean square } \\
\hline \multicolumn{2}{|c|}{ Treatment } & & 6 & $4.23^{* * *}$ & $2.35^{* * * *}$ \\
\hline \multicolumn{2}{|l|}{ Error } & & 63 & 0.22 & 0.52 \\
\hline
\end{tabular}

Differences in rooting were not associated with ethylene.

Auxin inhibitors have been used rarely to study the association of ethylene and root formation. Microcuttings responded to both auxin inhibitors, NPA and TIBA, with increased ethylene evolution (Tables 4 and 5, respectively). NPA, a specific inhibitor of polar auxin transport (Sussman and Goldsmith, 1981), had no influence on root count. Inhibition of rooting by TIBA when IBA was applied basally suggests a TIBA effect other than polar auxin transport inhibition. Certain properties of auxins shared by TIBA (Thompson et al., 1973) suggest competitive inhibition. The increase in ethylene evolution without increasing root count with NPA and the increase in ethylene evolution with loss of rooting from TIBA suggests that root initiation is not mediated by ethylene.

The association of ethylene with auxin in root formation was tested previously using $100 \mu \mathrm{m}$ or more AVG (Geneve et al. 1990b; Jusaitis, 1986; Riov and Yang, 1989). In the present study, $2 \mu \mathrm{M}$ AVG achieved inhibition of ethylene (Fig. 2) after $1 \mathrm{~d}$ of treatment. Adding $10 \mu \mathrm{M}$ AVG with 1.5 and $15 \mu \mathrm{M}$ IBA reduced ethylene evolution but also reduced root count (Table 2). When ethylene evolution was eliminated nearly by $10 \mu \mathrm{M}$ AVG, root count remained IBA dependent. This implies ethylene was not required for rooting unless a threshold level of ethylene below a detectable limit was available for root initiation.
Previous reports showed $V$. radiata developed more roots from ACC treatment, presumably through induction of ethylene (Jusaitis, 1986; Riov and Yang, 1989) or from ethylene treatment (Robbins et al. 1985). Ethylene treatment inhibited root development once primordia initiated, but did not inhibit initiation of primordia in juvenile $H$. helix petioles (Geneve et al., 1990a). Juvenile petioles required exogenous auxin for adventitious root formation. The present study focused on the initiation phase of adventitious root formation, in which no response to ACC (Table 3) or treatment with ethylene alone was observed.

Reversal of AVG rooting inhibition by ACC complicates the interpretation of ethylene's role in adventitious root formation (Table 3). Since ACC did not influence root count when AVG was omitted, even though ethylene evolution was stimulated, reversal of AVG rooting inhibition by ACC cannot be interpreted solely on the basis of ethylene evolution. Interpretation of the relationship of endogenous ethylene production to root formation is complicated further by the lack of localization of ethylene production to the region involved in root formation. Recently, mutant genotypes lacking sensitivity to or production of ethylene have been identified (Bleecker et al., 1988; Zobel, 1973). These genotypes should be useful in gaining a better understanding of ethylene involvement in adventitious root formation.

Table 4. IBA and NPA influence on ethylene evolution and root count of Malus domestica 'Gala' microcuttings.

\begin{tabular}{|c|c|c|c|}
\hline Main effect & $\mathrm{df}$ & Ethylene $\left(\mathrm{nl} \cdot \mathrm{g}^{-1} \cdot \mathrm{h}^{-1}\right)$ & Root count \\
\hline \multicolumn{4}{|l|}{ IBA $(\mu \mathrm{M})$} \\
\hline 0 & & 2.07 & 3.8 \\
\hline 1.5 & & 3.36 & 7.2 \\
\hline 15 & & 11.29 & 13.6 \\
\hline \multicolumn{4}{|l|}{ NPA $(\mu \mathrm{M})$} \\
\hline 0 & & 5.3 & 7.1 \\
\hline 1.5 & & 4 & 8.5 \\
\hline 15 & & 7.43 & 9.0 \\
\hline ANOVA $^{z}$ & & & \\
\hline IBA & 2 & $18.73^{* * * *}$ & $21.04^{* * * *}$ \\
\hline NPA & 2 & $2.43^{* *}$ & $0.82^{\mathrm{NS}}$ \\
\hline $\mathrm{IBA} \times \mathrm{NPA}$ & 4 & $0.22^{\mathrm{NS}}$ & $0.67^{\mathrm{NS}}$ \\
\hline Error & $63,81^{\mathrm{y}}$ & 0.34 & 0.3 \\
\hline
\end{tabular}

${ }^{\mathrm{z}}$ Analysis of variance on transformed data $(\sqrt{\mathrm{x}}+1)$. Nontransformed means presented.

${ }^{\mathrm{y} E t h y l e n e ~ e v o l u t i o n ~ a n d ~ r o o t ~ c o u n t ~ d e g r e e s ~ o f ~ f r e e d o m, ~ r e s p e c t i v e l y . ~}$

Ns, $* * * * * *$ Nonsignificant and significant at $P=0.01$ and 0.001 , respectively. 
Table 5. IBA and TIBA influence on ethylene evolution of Malus domestica 'Gala' microcuttings.

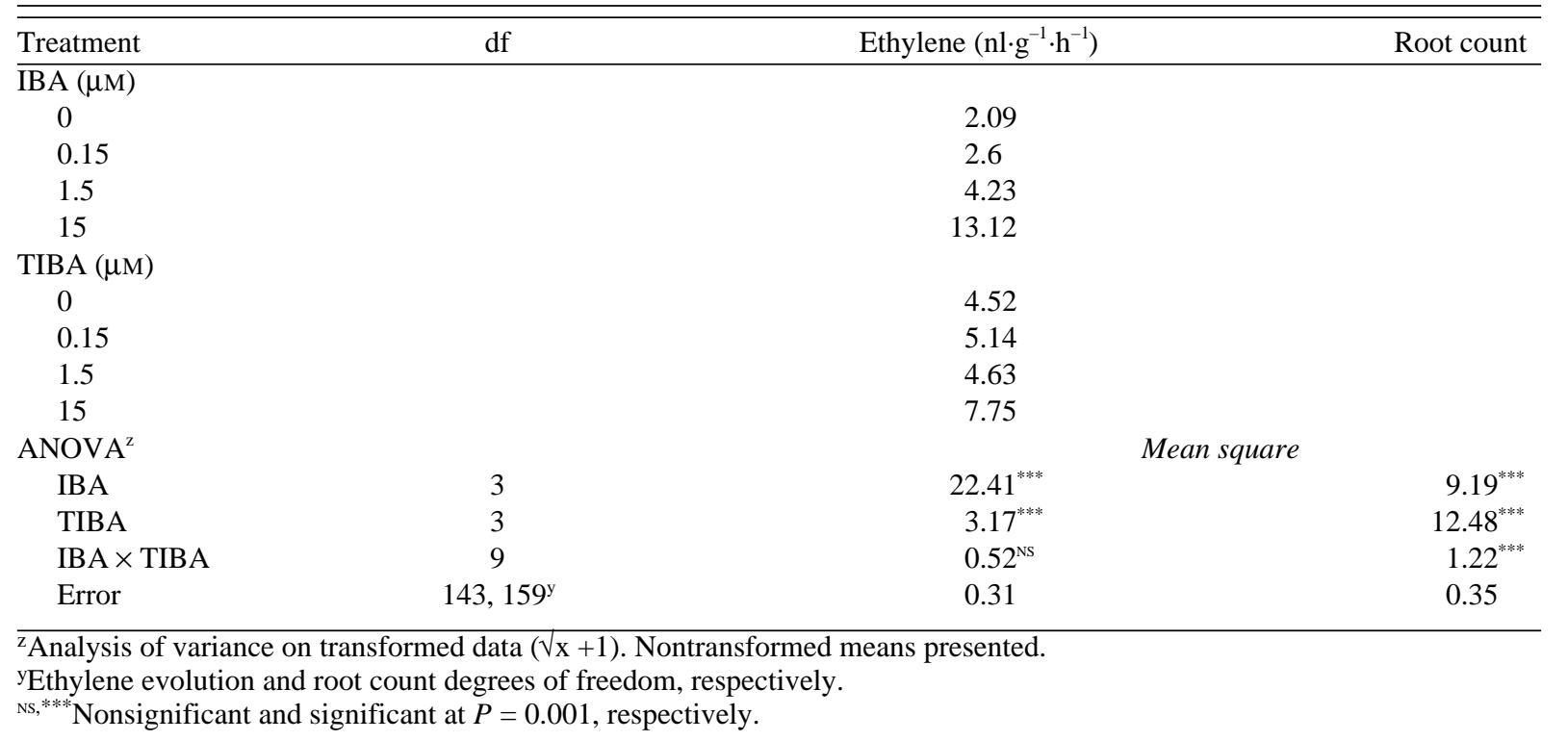

The stimulatory affect of ethylene gas and ACC-induced ethylene production on root count was studied previously on easily rooted herbaceous material that did not require exogenous auxin. Usually rooting was observed on intact plants (Mudge, 1988). Adventitious root formation response of difficult-to-root woody species to ethylene treatment has been examined rarely (Kumar et al., 1987). Although in vitro-cultured callus has been used to test the relationship between ethylene and root initiation, the use of microcuttings with a well defined root initiation phase and root development phase appears to be unique for this purpose. Ethylene was not essential for adventitious rooting of $M$. domestica microcuttings. This, however, should not preclude the possibility of ethylene's role in adventitious rooting in another plant system.

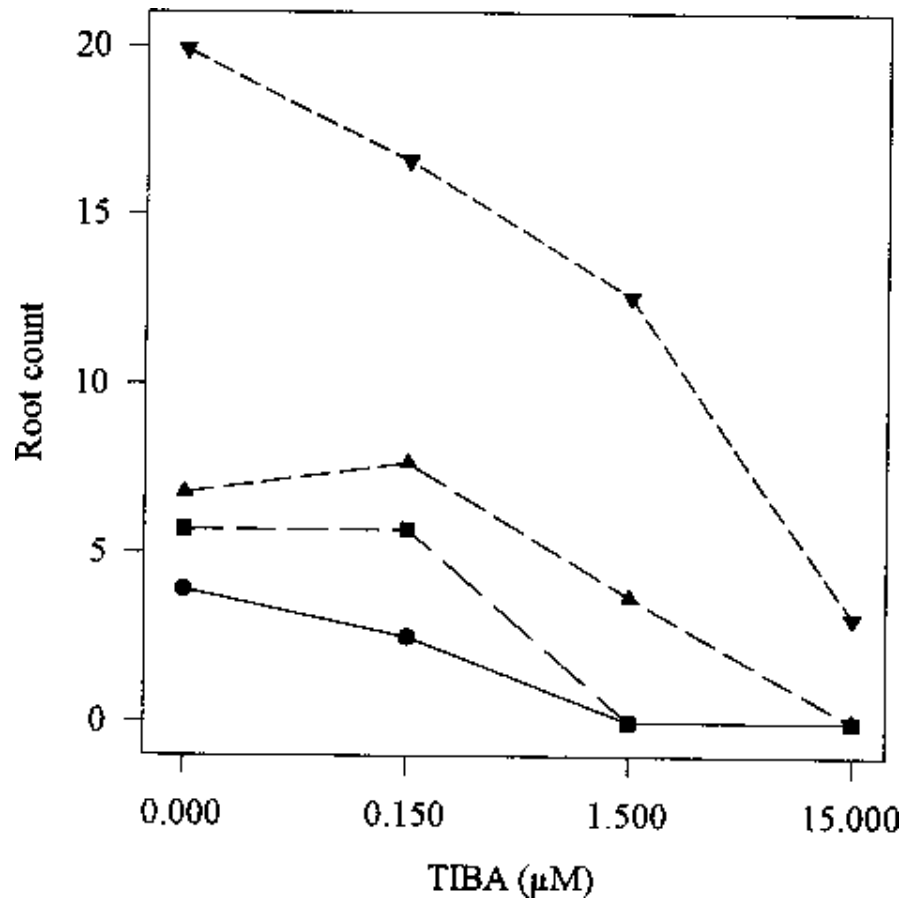

Fig. 3. IBA by TIBA interaction influence on root count of Malus domestica 'Gala' microcuttings. IBA concentration $(\mu \mathrm{M}): 0(\bullet) 0.15(\bigcirc), 1.5(\boldsymbol{\Delta})$, and $15(\boldsymbol{\nabla})$.

\section{Literature Cited}

Batten, D.J. and M.G. Mullins. 1978. Ethylene and adventitious root formation in hypocotyl segments of etiolated mung-bean (Vigna radiata (L.) Wilczek) seedlings. Planta 138:193-197.

Bleecker, A.B., M.A. Estelle, C. Somerville, and H. Kende. 1988. Insensitivity to ethylene conferred by a dominant mutation in Arabidopsis thaliana. Science 241:1086-1089.

Geneve, R.L., W.P. Hackett, and B.T. Swanson. 1990a. Ethylene production in debladed petioles from the juvenile and mature phases of english ivy in relation to adventitious root initiation. J. Amer. Soc. Hort. Sci. 115:123-127.

Geneve, R.L., W.P. Hackett, and B.T. Swanson. 1990b. Root initiation in debladed petioles from juvenile and mature english ivy in response to inhibitors of ethylene biosynthesis and action. J. Amer. Soc. Hort. Sci. 115:128-131.

Geneve, R.L. and C.W. Heuser. 1983. The relationship between ethephon and auxin on adventitious root initiation in cuttings of Vigna radiata (L.) R. Wilcz. J. Amer. Soc. Hort. Sci. 108:330-333.

Harbage, J.F., D.P. Stimart, and R. Evert. 1993. Anatomy of adventitious root formation in microcuttings of Malus domestica 'Gala'. J. Amer. Soc. Hort. Sci. 118:680-688.

Hess, C.E. 1968. Root induction. In: J.W. Mitchell and G.A. Livingston (eds.). USDA Agr. Handbook 336:76-77.

Jusaitis, M. 1986. Rooting of intact mung bean hypocotyls stimulated by auxin, ACC, and low temperature. HortScience 21:1024-1025.

Kumar, P.P., D.M. Reid, and T.A. Thorpe. 1987. The role of ethylene and carbon dioxide in differentiation of shoot buds in excised cotyledons of Pinus radiata in vitro. Physiol. Plant. 69:244-252.

Moncousin, C., J. Favre, and T. Gaspar. 1989. Early changes in auxin and ethylene production in vine cuttings before adventitious rooting. Plant Cell Tiss. Org. Cult. 19:235-242.

Mudge, K.W. 1988. Effect of ethylene on rooting. In: T.D. Davis, B.E. Haissig, and N. Sankhla (eds.). Adventitious root formation in cuttings. Dioscorides Press, Portland, Ore.

Mudge, K.W. and B.T. Swanson. 1978. Effect of ethephon, indole butyric acid, and treatment solution $\mathrm{pH}$ on rooting and on ethylene levels within mung bean cuttings. Plant Physiol. 61:271-273.

Murashige, T. and F. Skoog. 1962. A revised medium for rapid growth and bioassays with tobacco tissue cultures. Physiol. Plant. 15:473-497.

Riov, J. and S.F. Yang. 1989. Ethylene and auxin-ethylene interaction in adventitious root formation in mung bean cuttings. J. Plant Growth Regulat. 8:131-141.

Robbins, J.A., S.J. Kays, and M.A. Dirr. 1983. Enhanced rooting of wounded mung bean cuttings by wounding and ethephon. J. Amer. Soc. Hort. Sci. 108:325-329. 
Robbins, J.A., M.S. Reid, and T.L. Rost. 1985. The effect of ethylene on adventitious root formation in mung bean (Vigna radiata) cuttings. J. Plant Growth Regulat. 4:147-157.

Swanson, B.T. 1974. Ethrel as an aid in rooting. Proc. Intl. Plant Prop. Soc. 24:351-361.

Sussman, M.R. and M.H. Goldsmith. 1981. The action of specific inhibitors of auxin transport on uptake of auxin and binding of $\mathrm{N}-1$ naphthylphthalamic acid to a membrane site in maize coleoptiles. Planta 152:13-18.

Thimann, K.V. and J.B. Koepfli. 1935. Identity of the growth-promoting and root-forming substances of plants. Nature 135:101-102.

Thimann, K.V. and F.W. Went. 1934. On the chemical nature of the root forming hormone. Proc. K. Ned. Akad. Wet. Amst. 37:456-459.

Thompson, K.S., R. Hertel, S. Muller, and J.E. Tavares. 1973. 1-NNaphthylphthalamic acid and 2,3,5,-triiodobenzoic acid: In-vivo bind- ing to particulate cell fractions and action on auxin transport in corn coleoptiles. Planta 109:337-352.

Yu, Y.B. and S.F. Yang. 1979. Auxin-induced ethylene production and its inhibition by aminoethoxyvinylglycine and cobalt ion. Plant Physiol. 64:1074-1077.

Zimmerman, P.W., W. Crocker, and A.E. Hitchcock. 1933. Initiation and stimulation of roots from exposure of plants to carbon monoxide gas. Contrib. Boyce Thompson Inst. 5:1-17.

Zimmerman, P.W. and A.E. Hitchcock. 1933. Initiation and stimulation of adventitious roots caused by unsaturated hydrocarbon gases. Contrib. Boyce Thompson Inst. 5:351-369.

Zimmerman, R.H. and I. Fordham. 1985. Simplified method for rooting apple cultivars in vitro. J. Amer. Soc. Hort. Sci. 10:34-38.

Zobel, R.W. 1973. Some physiological characteristics of the ethylenerequiring tomato mutant diageotropica. Plant Physiol. 52:385-389. 